\title{
Cellulase Enzyme Production From Rice Straw Using Solid State Fermentation and Fungi Aspergillus niger ITBCC L74
}

\author{
Siti Maftukhah ${ }^{1 \cdot *}$, and Abdullah Abdullah ${ }^{2}$ \\ ${ }^{1}$ Master of Chemical Engineering, Diponegoro University, Indonesia, 50275 \\ ${ }^{2}$ Chemical Engineering Deparment, Diponegoro University, Indonesia, 50275
}

\begin{abstract}
Rice straw is one of very abundant waste of agricultural and has not utilized maximally. This waste contain cellulose and potential in the manufacture of cellulase enzymes. Research on the production of cellulase enzyme from lignocellulose has been done a lot of enzyme activity is still low. This research using cellulose is $71.95 \%$ and conducted with 6 stages. First, the preparation of raw material. Second, the decrease of lignin content with alkali pretreatment. Third, the breeding of fungi Aspergillus niger ITBCC L74 . Fourth, incubation in the inoculum. Fifth, the production of cellulase enzyme by solid fermentation method. Finally, the analysis includes protein content, enzyme activity, enzyme characterization and kinetics of enzymatic reactions. The highest enzyme activity of this study is $3.12 \mathrm{U} / \mathrm{ml}$ and protein content is $0.34 \mathrm{mg} / \mathrm{ml}$ with fermentation time is 4 day and water content is $75 \%$. In enzyme characterization obtained optimum $\mathrm{pH}$ and temperature are 4 and $60^{\circ} \mathrm{C}$, respectively. And obtained paramatic kinetic are $\mathrm{V}_{\max }$ and $\mathrm{K}_{\mathrm{m}}$ for $40,50,60$ and $70^{\circ} \mathrm{C}$ temperature are $\mathrm{V}_{\max }: 6.42 ; 4.7 ; 5.82$ and $4.46 \mathrm{U} / \mathrm{ml}$ and $\mathrm{K}_{\mathrm{m}}: 1.32$; 0.38 ; 0.32 ; and $0.12 \%$, respectively.
\end{abstract}

\section{Introduction}

One of the most abundant agricultural residues available in the world is rice straw. And usully the word produced rice straw are731 million tons, consists of Africa: 20.9 million tons, Asia: 667.6 million tons, Europe: 3.9 million tons, America: 37.2 million tons and Oceania: 1.7 million tons [1] and overall in the word, rice straw production of 650-975 tons per year [2]. According to data from BPS in 2016 [3], rice production is 75.36 million tons of dried unhulled rice so the potential of rice straw in Indonesia is about 105.80 million tons [20]. Overall, the used of rice straw as fodder, fertilizer of organic and be berned $[2,4,5,6]$. Production of rice straw is very high and the utilization is not maximal because most of the cellulose content can not be fully utilized [7] makes rice straw very potential to be used as feedstock for biofuel production $[2,5]$.

With the decline of petroleum production, energy sources are needed to meet future needs [8]. From to Pertamina's data, consumption of national fuel during 2000 to 2011 is about 312 to $364 \mathrm{~m}$ barrels of oil and the equivalent increases annually. Fuels of fossil is not environmentally friendly because produce a lot of pollution. For that needed a renewable energy source from biomass that environmentally friendly [22]. One of it is the biofuel production from lignocelluloses through hydrolysis and enzymatic fermentation processes, example bioethanol that can use enzymes from fungi that produce glucose, followed by fermentation of glucose into ethanol [9].
Rice straw is waste with cellulose content can be utilized as substrate for production of cellulase enzyme. Cellulase enzyme is an important enzyme because it have a role in the conversion and processing of materials in various fields. Of the total enzyme trade, $20 \%$ are cellulase enzymes [10] and increased enzyme demand along with the utilization of cellulase enzymes in the beverage, food, detergent, pulp and paper industries, ethanol, pharmaceuticals and others [9-13]. The use of enzymes on a large scale is still limited by cost factors. Some of the strategies for reducing the cost of cellulose enzymes include: increased enzyme productivity, enzyme production with cheaper substrate, and cellulase production with higher activity [14-16] .

The production of cellulase enzymes from biomass is one of way to decrease the price of cellulase enzymes [16] and increase the value of agricultural waste $[5,17]$. Production of cellulase enzymes from various agricultural wastes has been widely practiced but the resulting enzyme activity is still low. Cellulase enzymes are synthesized from various microbes so that selection of microbial types also greatly affects enzyme productivity. Abdullah [18] conducted research on water hyacinth, rice straw and corn cob and obtained the highest enzyme activity of rice straw substrate of 2.57 $\mathrm{U} / \mathrm{ml}$. Improvement of enzyme productivity in this study started from pretreatment to decrease lignin content, use of fungal strains that have high cellulase enzyme activity, use of appropriate fermentation method and use of optimum fermentation conditions. 
The purpose of this research is to study the pretreatment effect of rice straw substrate in cellulase enzyme activity, to obtain optimum condition of moisture content and fermentation time to cellulase enzyme activity, characterization the highest activity of crude enzymes by determining the optimum of $\mathrm{pH}$ and temperature of the enzymatic reaction and to determine kinetics parameter of enzymatic reaction from the highest activity of crude enzymes.

\section{Materials and Methods}

\subsection{Material}

Raw materials in this study used post harvest rice straw obtained from Jepara, Central Java. Fungi Aspergilus niger ITBCC L 74 was purchased from Microbiology Laboratory and Bioprocess, Chemical Engineering Department, Bandung Institute of Technology. Aquades obtained from the Reverse Osmosis Unit are available in the Membrane Research Center Laboratory, Diponegoro University. And chemical reagents used with quality analysis $(\geq 9.90 \% \mathrm{w} / \mathrm{w})$ such as phenol fenol, DNS, BSA, PDA.

\subsection{Methods}

\subsubsection{Preparation of material}

Preparation of raw material was done by dried the rice straw in the sun, then cut, crushed and sieved so that obtained by rice straw powder with maximal water content (AOAC, 1990) [19] of 10\% and pass $1 \mathrm{~mm}$ sieve [17]. Analysis of lignocellulosic content with Cesson Datta Method, protein content with Kjeldahl Method and ash content with thermogravimetri method conducted in food and nutrition laboratories Gajah Mada University..

\subsubsection{Pretreatment}

Pretreatment was done by adding $2.75 \% \mathrm{NaOH}$ solution of $1: 10(\mathrm{w} / \mathrm{v})$ ratio of rice straw powder, then the mixture was heated by hot plate stirrer at $100^{\circ} \mathrm{C}$ for 80 minutes. After cold, the mixture was neutralized on the filter paper and vacuum filter using $0.2 \mathrm{~N} \mathrm{HCl}$ solution up to $\mathrm{pH}$ 7. The solid was dried using a oven in $70^{\circ} \mathrm{C}$ to a constant water content. After cold the substrate was stored in plastic equipped with silica gel [17]. Analysis is done as in rice straw before pretreatment

\subsubsection{Cultivated of microbes}

Fungi Aspergillus niger ITBCC L74 is cultivated on medium of Potato Dextro Agar (PDA). Fungi applied zig-zag on PDA media using ose wire on aseptic condition. Then the fungi were incubated at temperature of $30 \pm 2^{\circ} \mathrm{C}[8,21]$.

\subsubsection{Inoculation in the inoculum}

Inoculum was obtained by adding pure culture of Aspergillus niger ITBCC L74 into inoculum of medium solution. Inoculum of medium solution used $50 \mathrm{ml}$ glucose solution $10 \mathrm{~g} / \mathrm{l}$, then added $5 \mathrm{ml}$ the solution of nutrition according to Mendels prescription : $\left(\mathrm{NH}_{4}\right)_{2} \mathrm{SO}_{4}$ 1.4 gram; $\mathrm{KH}_{2} \mathrm{PO}_{4} 2.0$ gram, urea 0.3 gram; $\mathrm{MgSO}_{4} .7 \mathrm{H}_{2} \mathrm{O} 0.3$ gram; $\mathrm{ZnSO}_{4} .7 \mathrm{H}_{2} \mathrm{O} 0.0014$ gram; $\mathrm{FeSO}_{4} .7 \mathrm{H}_{2} \mathrm{O} 0.005$ gram; $\mathrm{MnSO}_{4} 0.0016$ grams; $\mathrm{CoCl}_{2}$ 0.002 grams; $\mathrm{CaCl}_{2} 0.002$ grams; Tween-80 $2.0 \mathrm{ml}$ and 1.0 gram pepton and aquades added to volume $1 \mathrm{~L}$. Set the $\mathrm{pH}$ to 3.5 and sterilization. After cold, added the microbes and the inoculum was incubated at $30^{\circ} \mathrm{C}[8]$.

\subsubsection{Cellulase enzymes production}

Production of cellulase enzyme was done by put the sample in to erlen meyer flask, then add the nutrients solution $[8,34]$ and water to the water content of $60 \%$, $65 \%, 70 \%, 75 \%$ and $80 \%[8,18,33]$ And set the $\mathrm{pH}$ to $\mathrm{pH} 3.5$ [8].Next done sterilization. After cold, added the incubated inoculum of $1 \times 10^{6}$ spores/ml [12]. Subsequently, the mixture was incubated at $30 \pm 2^{\circ} \mathrm{C}$ with fermentation timeof $3,4,5$ and 6 days $[8,16,18,33]$.

\subsubsection{Extraction of enzyme}

Taking the enzyme started by extracting the fermentation result with a ratio of substrate : aquades was $1: 50(\mathrm{w} / \mathrm{v})$ using a funnel and filter paper on $250 \mathrm{ml}$ beaker glass. The filtrate was shaken using incubator shaker at 200 $\mathrm{rpm}$ at $30^{\circ} \mathrm{C}$ for 1 hour. Supernatant was obtained after centrifuge at $6000 \mathrm{rpm}$ for $15 \mathrm{~min}$ and continued with analysis [16].

\subsubsection{Cellulase enzyme assay}

According to Abdeshahian et al., [21] the first analysis was a protein content by Lowry method to know the presence of enzymes in sample [23]. And enzyme activity is determined by the initial treatment of taking 1 $\mathrm{ml}$ of crude enzyme inserted in erlen meyer. Then adding $1 \% \mathrm{CMC}(\mathrm{w} / \mathrm{v})$ and $0.1 \mathrm{M}$ buffer of sodium citrate solution ( $\mathrm{pH} 4.8$ ). The mixture was incubated at $40^{\circ} \mathrm{C}$ for 30 minutes. The reducing sugar is measured by DNS method (3,5-dinitrosalicylic acid) [24]. One unit (U) of enzyme activity is the amount of enzyme required to produces $1.0 \mu \mathrm{mol}$ of glucose per minute under the assay conditions.

The enzyme characterization is performed on the enzyme which has the highest activity by varying the $\mathrm{pH}$ and temperature.

To determine the kinetic parameter by altering the substrate concentration (S) in the enzyme activity test of the crude enzyme having the highest enzyme activity performed at $40,50,60$ and $70^{\circ} \mathrm{C}$. Different substrate concentrations resulted in different enzyme activity $\left(\mathrm{V}_{0}\right)$. $1 / \mathrm{S}$ and $1 / \mathrm{V}_{0}$ graphs are obtained so that $1 / \mathrm{K}_{\mathrm{m}}$ and $1 /$ Vmax of each temperature are obtained based on the Michaelis-Menten equation. 


\section{Results and Discussions}

\subsection{Effect of pretreatment on cellulase enzyme activity}

he result of raw material characterization is presented in Table 1.

\begin{tabular}{lcc} 
& Table 1. Result of raw material analysis \\
\hline Parameter & Without pretreatment (\%) & With alkali pretreatment (\%) \\
\hline Cellulase & 42.26 & 71.95 \\
Hemicellulose & 9.79 & 13.23 \\
Lignin & 11.28 & 7.08 \\
Protein & 5.11 & 1.14 \\
Ash & 4.92 & 5.12 \\
\hline
\end{tabular}

Pretratment or delignification is a process of altering the chemical structure of lignocellulosic biomass in order to degrade lignin selectivity so as to decompose chemical bonds and other components are kept intact [25]. Cellulose and hemicellulose are carbohydrate structures in rice straw that can be depolymerized by enzymatic hydrolysis to glucose [17]. Pretreatment needs to be done because the presence of lignin in the material can inhibit cellulosic digestion during enzymatic hydrolysis [26] and microbial fermentation [27].

From Table 1. it can be seen that pretraetment causes content of cellulose increased by $70.25 \%$, hemicellulose content increased by $35.14 \%$ and lignin content decreased by $59.32 \%$. This is caused because alkaline pretreatment can remove lignin without affecting the other components. Pretreatment using $\mathrm{NaOH}$ causes a reduction of linin in the material, increased surface area, increased pore size, and the breaking of bonds between lignin and cellulose and hemicellulose as soon as to decrease the degree of crystallinity [28]. The increase in cellulose during alkaline pretreatment is largely due to the decrease in lignin. Lignin decreases as it dissolves in an alkaline solution [17].

From the Table 1 too. can also be seen that the protein content decreased 3 fold. This is because the protein starts denatured at $45^{\circ} \mathrm{C}$ [29]. Proteins are amino acids that have elements $\mathrm{C}, \mathrm{H}, \mathrm{O}, \mathrm{N}$ as nutrients to produce enzymes. Carbon acts as an enzyme cofactor while nitrogen is required in the fermentation process because affect the activity of Aspergillus niger. In it growth, carbon and nitrogen are used for the body's fungi cell components [18].

For ash content does not change because $\mathrm{NaOH}$ only removes lignin without other components [17].

Thus, when compared with the research of Abdullah [18] the production of cellulase enzymes without pretreatment using the same substrate, fungi and method and using conditions slightly different from this research using $\mathrm{pH} 4$, the highest cellulase enzyme activity increased $21.40 \%$. Or the highest enzyme activity in the study of Abdullah [18] is $2.57 \mathrm{U} / \mathrm{ml}$. While in this research the highest cellulase enzyme activity is 3.12 $\mathrm{U} / \mathrm{ml}$ at $75 \%$ moisture content and 4 day fermentation time. This phenomenon can be seen in Figure 1. It is also revealed by Ilyas [28] that the activity of cellulase enzyme using pretretment increased by $51 \%$ compared with without pretreatment on Vigno mungo substrate.

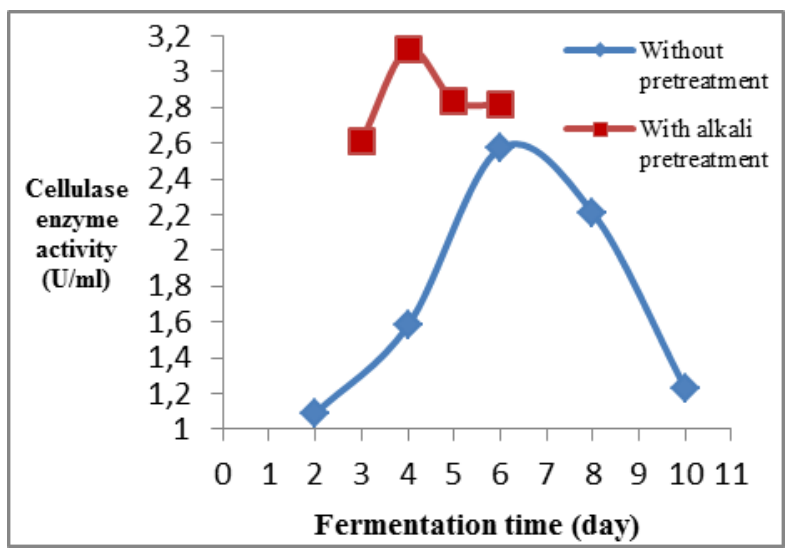

Fig. 1. Cellulase enzyme activity with pretreatment and without pretreatment

3.2 Effect of water content and length of fermentation on cellulase enzyme activity 3.2.1 Effect of water content on cellulase enzyme activity

Growth, biosynthesis and enzyme secretion of microbes affected by water content because it is an important factor in solid state fermentation [30]. The effect of water content to cellulase enzyme activity in this study can be seen in Fig 2.

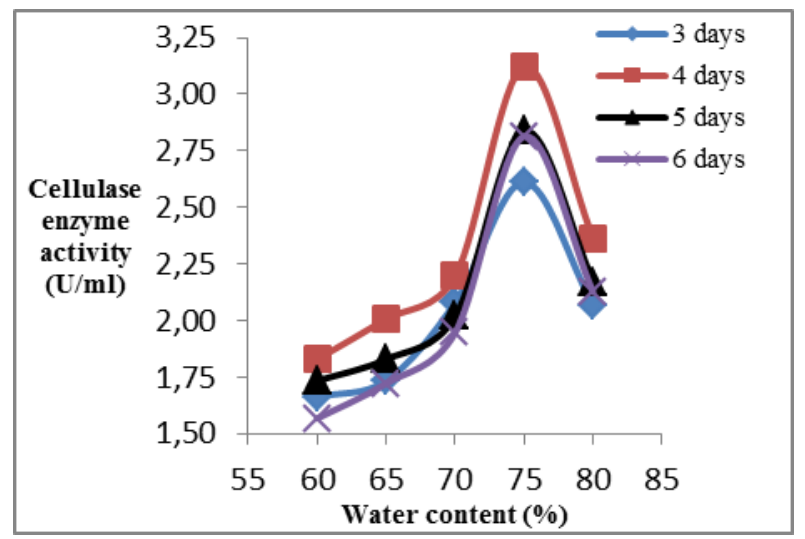

Fig. 2. Effect of water content on cellulase enzyme activity

Enzyme activity will increase with increasing of water content and optimum enzyme activity at $75 \%$ water content with 4 days of fermentation time is 3.12 $\mathrm{U} / \mathrm{ml}$. However, enzyme activity decreased at $80 \%$ water content. This phenomenon is the same for all variations of fermentation time. The water content is low to cause low growth of microbes, as well as low development and accessibility of nutrients. While the water content is high resulted in decreasing porosity of the substrate so reducing the penetration of oxygen to the particles [16].

Abdullah [18] conducted a study on rice straw using Aspergillus niger ITBCC L 74 and obtained the highest cellulase enzyme activity at $80 \%$ water content. While Ilyas [28] conducted a study of cellulase enzyme production from Vigno mungo and fungi Aspergillus 
niger, obtained the highest activity at $70 \%$ water content. This is agree with a statement from Ganjdar [31] that Aspergillus niger can grow well on water content of 70$80 \%$.

The presence of protein content in a substance indicates the presence of an enzyme in the material. Increased protein content along with the growth of mold (fungi) because the fungus body consists of elements containing nitrogen. And the enzyme produced by the fungus is also a protein. The cell wall of the fungus contains $6.3 \%$ protein, while fungal cell membranes with hyphae contains $25-45 \%$ protein and $25-30 \%$ carbohydrates. In its growth, fungi using carbon and nitrogen for the fungus body cell components. This process occurs because during the fermentation of Aspergillus niger ITBCC L74 using nutrients (especially carbohydrates) for growth and increased protein content. [18]. The effect of water content on protein content can be seen in Fig 3.

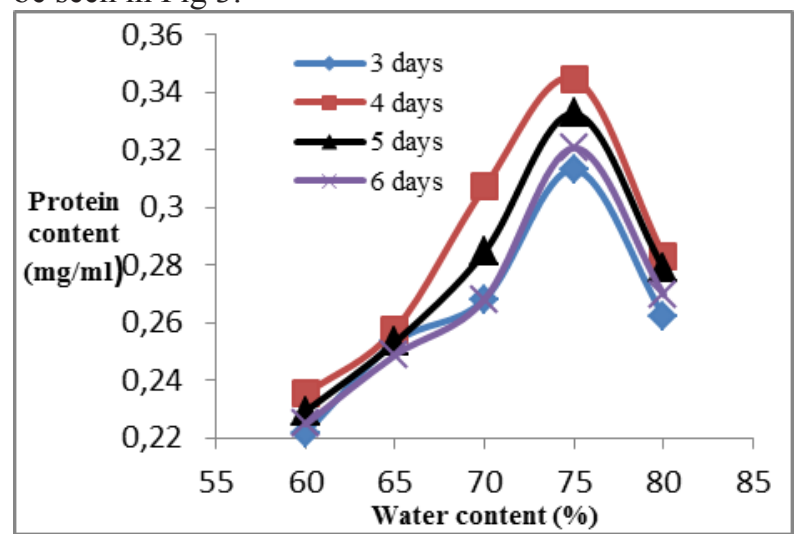

Fig. 3. Effect of water content on protein content

The highest protein content was obtained at $75 \%$ water content of $0.34 \mathrm{mg} / \mathrm{ml}$ with 4 days of fermentation and the lowest protein content obtained at $60 \%$ water content and 3 days fermentation time of $0.22 \mathrm{mg} / \mathrm{ml}$. Aspergillus niger in growth media containing complex molecules can secrete extracellular enzymes such as $\alpha$ amylase, $\beta$-amylase, glucoaamylase, protease and cellulase [32]. Based on the results of this study obtained increase in cellulase enzyme activity along with the increase in protein content. This is because most of the proteins in the crude enzyme filtrate consist of cellulase enzymes [9-10].

\subsubsection{Effect of fermentation time on the cellulase enzyme activity}

The effect of fermentation time on the cellulase enzymes activity can be seen in Fig 4.

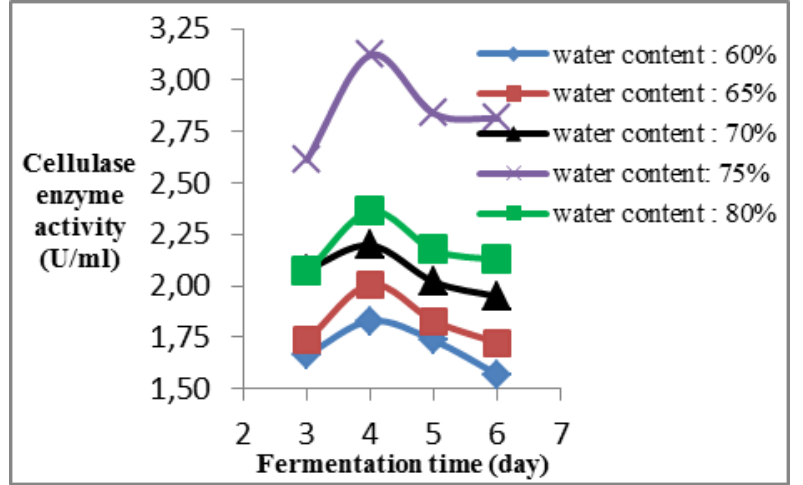

Fig. 4. Effect of fermentation time on cellulase enzyme activity

From the Fig 4. it can be seen that the highest cellulase enzyme activity is obtained at the time of fourth day fermentation for all variations of water content. Enzyme activity increases with fermentation time. However, enzyme activity decreased on the fifth and sixth days. In the beginning fermentation of enzyme activity is still very low. Enzyme activity increases with increasing fermentation time and decreases when available nutrients are depleted [32]. It follows the growth pattern of microorganisms. Spore-forming organisms usually produce enzymes in the post exponential phase. So when the enzyme activity produced is high, then the mold has been in that phase [7].

Ilyas [28] conducted a production study of cellulase enzyme from Vigno mungo, using the same method and temperature with this study and the same fungi but different strains, obtained the highest enzyme activity is $0.398 \mathrm{U} / \mathrm{ml}$ at 4 day fermentation. And Kang [33] also produced cellulase enzymes with similar methods and substrate types with this study and the same fungi but different strains, and obtained the highest enzyme activity on the fifth to sixth day of fermentation. And Omojasola [34] performed the cellulase enzymes production with pineapple waste substrate and the same conditions of various fungi types, obtained enzyme activity of $1.71 \mathrm{U} / \mathrm{ml}$ by Trichoderma longibrachiatum, $1.29 \mathrm{U} / \mathrm{ml}$ by Aspergillus niger and $1.07 \mathrm{U} / \mathrm{ml}$ by Saccharomyces cereviseae on the third and fifth day of fermentation. Various optimum fermentation periods for cellulase enzyme production due to differences in medium properties, types of microorganisms, nutrient concentrations and physiological conditions of the process used [35].

The effect of fermentation time to protein content is presented in Fig 5. 


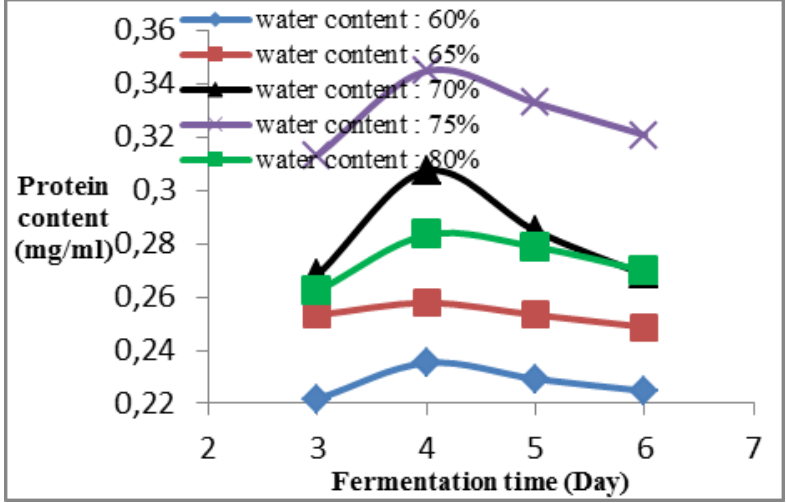

Fig. 5. Effect of fermentation time on protein content

As with enzyme activity, the effect of protein content on fermentation time is obtained by the highest value at 4 days of fermentation time for all variations of water content.

\subsection{Effect of $\mathrm{pH}$ and temperature on cellulase enzyme activity}

3.3.1 Effect of $\mathrm{pH}$ on enzyme activity The active site of the enzyme having the ion group must be in the appropriate form (acid or base) in order to function. The variation in $\mathrm{pH}$ of the medium results in ion-formation of the active site and changes in enzyme activity so as to influence the rate of reaction. Changes in $\mathrm{pH}$ can also to change the dimensions of the enzyme. Or in other words, the enzyme has an active site with certain groups acting as a catalyst in the formation of the substrate (ES) complex. Changes in $\mathrm{pH}$ affect to the ionisation of functional groups, which can cause changes in enzyme conformation and its catalytic properties. For this reason the enzyme is only active in a certain $\mathrm{pH}$ range. Maximum reaction rate, $\mathrm{K}_{\mathrm{m}}$ and the stability of the enzyme are influenced by the $\mathrm{pH}$ of the medium [36].

The effect of $\mathrm{pH}$ on enzyme activity with $1 \%$ substrate concentration on production of cellulase enzyme having the highest activity is presented in Fig 6.

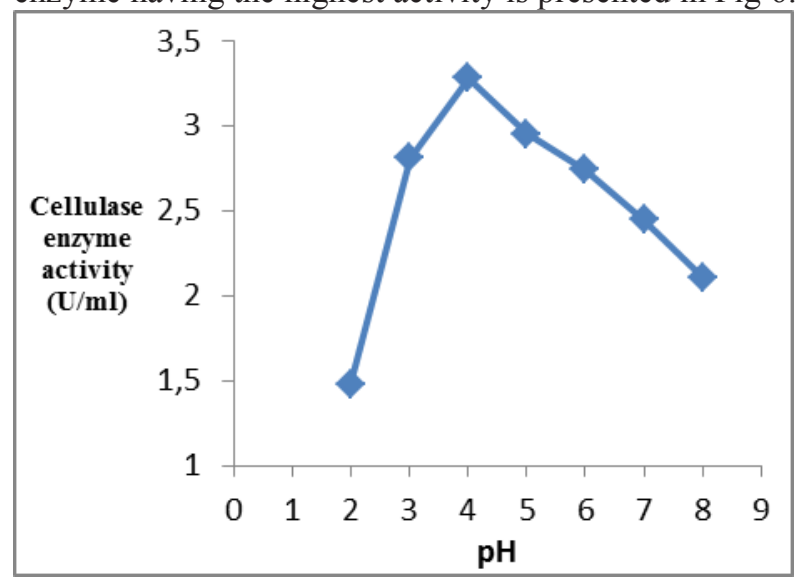

Fig. 6. Effect of $\mathrm{pH}$ on cellulase enzyme activity

From the Fig 6. it can be seen that the cellulase enzyme activity at $\mathrm{pH} 2$ is still low and increases at $\mathrm{pH} 3$ and 4 . The highest activity is obtained at $\mathrm{pH} 4$ is 3.28 $\mathrm{U} / \mathrm{ml}$ and its activity decreases up to $\mathrm{pH} 8$, and the decrease is apparent up to $55.45 \%$. According to the statement of Mustafa [13] that optimum cellulase enzyme activity at $\mathrm{pH} 4$ to 6.5 . And Liu [37] stated that the optimum cellulase enzyme activity at $\mathrm{pH}$ between 3 and 6. Similarly, it is in accordance with a study conducted by Delabona [38] that conducted a study of Aspergillus fumigates with wheat bran substrate obtained the highest activity at $\mathrm{pH}$ 5. In another study also obtained the activity of the highest cellulase enzyme at $\mathrm{pH} 4.5$ by Aspergillus niger [39]. As well as research from Aspergillus tereus obtained optimum activity at $\mathrm{pH}$ $5.5[13]$.

\subsubsection{Effect of temperature on enzyme activity} Temperature is one of the environmental factors that influence the development of enzyme activity. The rate of the enzyme-catalyst reaction increases with increasing temperature to some extent. The temperature rise will increase the reaction rate to only a certain range. At first the rate of reaction increases with increasing temperature and and the increase in rate in reaction is caused by the increased kinetic energy of the reacting molecules. Higher energy increases will break the weak hydrogen and hydrophobic bonds that retain the secondary-tertiary structure of the enzyme. In addition, high temperatures may also affect substrate conformation and thus experience resistance to entering the active site of the enzyme. Above a certain temperature, enzyme activity decreases due to enzyme denaturation [36] is changes in the structure of enzyme proteins, changes in ionic bonds and hydrogen bonds, so causing a decrease in reaction velocity catalyzed by the enzyme [40].

The effect between temperature to enzyme activity at $\mathrm{pH} 4$ of the enzyme crude of this study, which has the highest cellulase enzyme activity is presented in Fig 7.

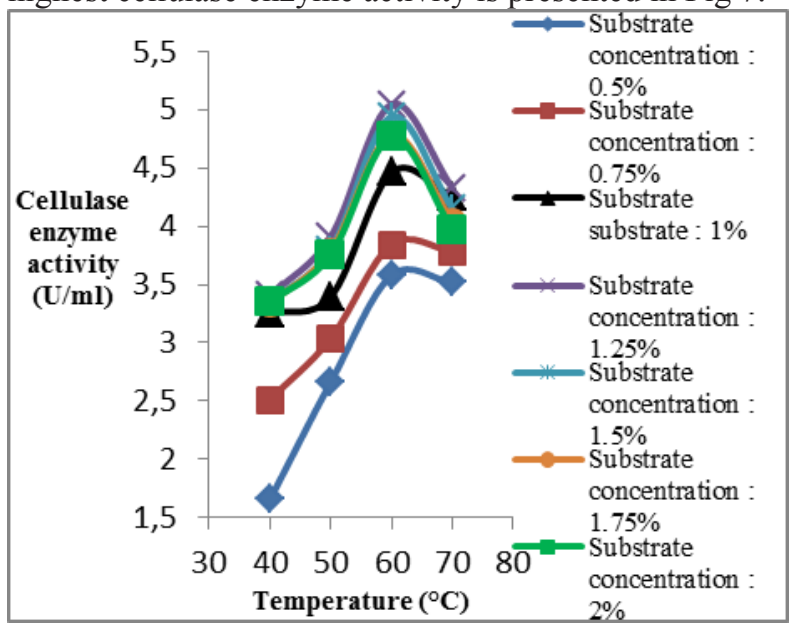

Fig. 7. Effect of temperature on cellulase enzyme activity

From the four variations of substrate concentration the phenomenon that occurs is the same that at first enzyme activity is still low and the increasing temperature, enzyme activity is also increasing. Then the enzyme activity decreases after the temperature of $60^{\circ} \mathrm{C}$. The highest enzyme activity occurred at $60^{\circ} \mathrm{C}$ and $\mathrm{CMC}$ concentration $1.25 \%$ at $5.05 \mathrm{U} / \mathrm{ml}$. 
Cellulase enzyme is a thermophilic enzyme with maximum activity between 50 and $65^{\circ} \mathrm{C}$. Higher temperatures may increase the formation of products, therefore cellulase enzymes have a potential use in industry [38]. Similarly, other studies such as those conducted by Falkoski [41] is production cellulase enzyme by the plant pathogenic fungus Chrysoporthe cubensis obtained the highest enzyme activity at $60^{\circ} \mathrm{C}$. While research conducted by Liu [37] from Aspergillus fumigatus obtained optimum temperature at $50^{\circ} \mathrm{C}$. Research conducted by Mustafa [13] from Aspergillus Tereus is optimum at $60^{\circ} \mathrm{C}$. As well as research conducted by Saini [42], from Penicillium oxalicum obtained the highest enzyme cellulase activity at $50^{\circ} \mathrm{C}$.

\subsection{Kinetics of Enzymatic Reactions}

Determination of maximum the rate of reaction $\left(\mathrm{V}_{\max }\right)$ and constants of Michaelis-Menten $\left(\mathrm{K}_{\mathrm{m}}\right)$ is an important thing to do to know the enzyme's characteristics [43]. The $V_{\max }$ value indicates the saturation level of the enzyme by the substrate, while $\mathrm{K}_{\mathrm{m}}$ indicates the catalyst efficiency of the enzyme defined as a substrate concentration at a time when the enzyme's catalytic velocity reaching half of its maximum rate [44]. The $\mathrm{K}_{\mathrm{m}}$ value used as an affinity measure E-S also relates to the desosiation balance equilibrium constant of the E-S complex becomes $\mathrm{E}$ and $\mathrm{S}$. Adding when the $\mathrm{K}_{\mathrm{m}}$ value is small means the E-S complex is steady and the enzyme affinity to the substrate is high, if $\mathrm{K}_{\mathrm{m}}$ value of enzyme is large so become low. $K_{m}$ value varies greatly depending on the type of substrate, the state of the environment and ionic strength[45].

Based on the Michaelis-Menten equation, the effect between substrate concentration and cellulase activity at 40, 50, 60 and $70^{\circ} \mathrm{C}$ temperature can be presented in Fig 8.

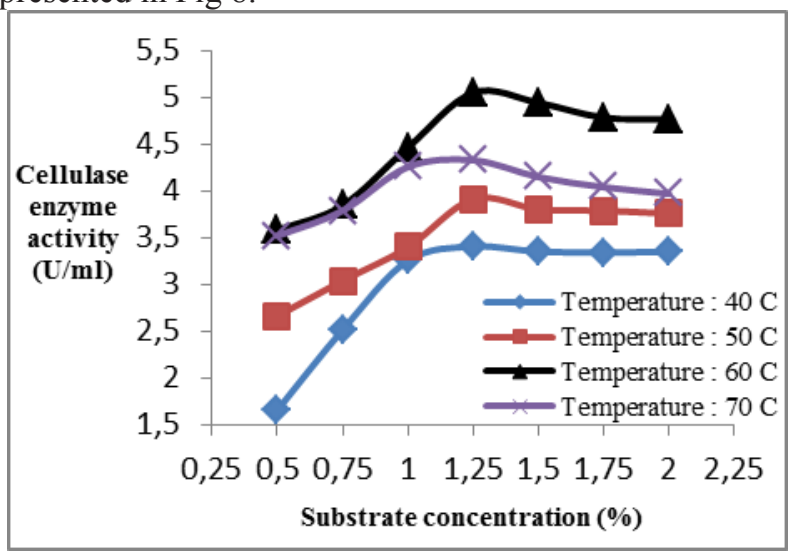

Fig. 8. Effect of substrate concentration on cellulase enzyme activity

Based on the kinetic theory, the higher the substrate concentration, the higher the energy and the frequency of collisions between molecules so that more cellulase enzymes can bind cellulose to form glycosylenzyme complexes which will further form glucose products [43]. It can be shown in Fig 8. that as the concentration of substrate increases then the activity of the enzyme is also increased. Nevertheless, the increase in enzyme activity will stop when the enzyme is saturated with the substrate because the molar amount of the substrate has exceeded the molar amount of the enzyme after the maximum limit point $\left(\mathrm{V}_{\max }\right)$ of the enzymatic reaction.

$\mathrm{V}_{\max }$ and $\mathrm{K}_{\mathrm{m}}$ values can be determined by transforming the Michaelis-Menten equation into the Lineweaver-Burk equation and obtain the graph as in Fig 9.

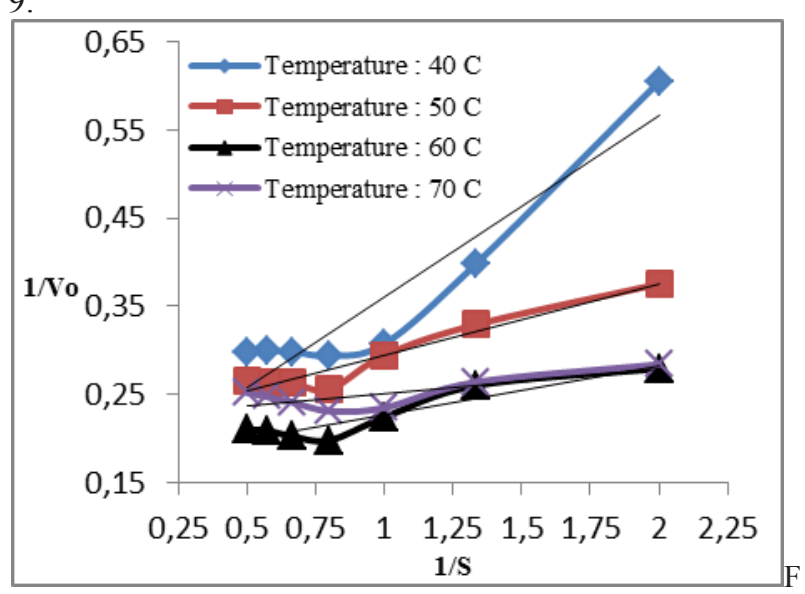

Fig. 9. Correlation between $1 / \mathrm{V}_{0}$ with $1 / \mathrm{S}$ based on the Lineweaver-Burk equation

Based on the Fig. 9 obtained linear equations, $V_{\max }$ and $\mathrm{K}_{\mathrm{m}}$ values of each temperature variation presented in Table 2.

Table 2. Parametic of kinetic reaction enzimatic

\begin{tabular}{ccccc}
\hline Temperature $\left({ }^{\circ} \mathrm{C}\right)$ & Linier equestion & $\mathrm{R}^{2}$ & Vmaks $(\mathrm{U} / \mathrm{ml})$ & $\mathrm{Km}(\%)$ \\
\hline 40 & $\mathrm{y}=0.2053 \mathrm{x}+0.1558$ & 0.8949 & 6.42 & 1.32 \\
50 & $\mathrm{y}=0.0813 \mathrm{x}+0.2129$ & 0.9364 & 4.7 & 0.38 \\
60 & $\mathrm{y}=0.0553 \mathrm{x}+0.1719$ & 0.8757 & 5.82 & 0.32 \\
70 & $\mathrm{y}=0.0271 \mathrm{x}+0.2243$ & 0.6076 & 4.46 & 0.12 \\
\hline
\end{tabular}

From Table 2. the difference in $\mathrm{V}_{\max }$ and $\mathrm{K}_{\mathrm{m}}$ values at each temperature was due to the reaction of enzyme catalysts with different temperatures causing different reaction rates. An increase in the external temperature will generally increase the rate of chemical reaction of the enzyme, but too high temperature rise will cause enzyme denaturation [36]. Excessive heat energy can increase the enzyme's kinetics to reach the point that can exceed the energy limit required to destroy the covalent bonds that make up the enzyme structure. As a result the polypeptide chain becomes unfolded or denatured and is accompanied by a dramatic decrease in catalytic activity [40].

Mustafa [13] conducted a study of cellulase enzyme production from Aspergillus terreus culture filtrate and Allium cepa seed sextract. The $\mathrm{K}_{\mathrm{m}}$ and $\mathrm{V}_{\max }$ for cellulase from FCF and OSE were 20 and $8 \mathrm{mg} / \mathrm{ml}$ and 10 and $2.78 \mathrm{U} / \mathrm{ml}$, respectively. Saropah [43] conducted a kinetics study of enzymatic reactions of crude extract enzyme cellulase cellulolytic bacteria isolated from bran and obtained values of $\mathrm{K}_{\mathrm{m}}$ and $\mathrm{V}_{\max }$ respectively are $1.694 \%$ and $0.0086 \mathrm{ppm} /$ minute. The difference in $\mathrm{V}_{\max }$ and $\mathrm{K}_{\mathrm{m}}$ values is caused because the enzyme extracted from different sources will have different properties, especially its response to environmental conditions, such as: temperature and $\mathrm{pH}$ [45]. 


\section{Conclusion}

Production of cellulase enzyme from rice straw using fungi Aspergillus niger ITBCC L74 and solid state fermentation method successfully done. By doing pretreratment on the substrate used, can increase cellulase enzyme activity is $21.40 \%$. And the variables studied in this research are water content and fermentation length. The highest enzyme activity was obtained at $3.12 \mathrm{U} / \mathrm{ml}$ at $75 \%$ water content and 4 days of fermentation time.

Enzyme activity is affected by $\mathrm{pH}$ and temperature. From the cellulase enzyme produced and the highest activity, the effect of $\mathrm{pH}$ and temperature on enzyme activity is studied. And the highest enzyme activity was obtained at $\mathrm{pH} 4$ and temperature $60^{\circ} \mathrm{C}$ is $5.05 \mathrm{U} / \mathrm{ml}$.

From the kinetics of the enzymatic reaction at 40.50 .60 and $70^{\circ} \mathrm{C}$ temperature obtained paramatic kinetic are $\mathrm{V}_{\max }: 6.42 ; 4.7 ; 5.82$ and $4.46 \mathrm{U} / \mathrm{ml}$ and $\mathrm{K}_{\mathrm{m}}$ : $1.32 ; 0.38 ; 0.32$ and $0.12 \%$.

\section{Acknowledgement}

We thank you to Bioprocess Laboratory of Chemical Engineering Department in Diponegoro University for all the support and facilities.

\section{References}

1. A.Ranjan, V.S. Moholkar. Fuel, 112, 567-571. (2013)

2. G.W. Park, H.N. Chang, K. Jung, C. Seo, Y. Kim, J.H. Choi, H.C. Woo, I. Hwang. Proc. Biochem. (2017)

3. Badan Pusat Statistik (2016)

4. D. She, X.N. Nie, F. Xu, Z.C. Geng, H.T. Jia, G.L. Jones. Cellulose Chem. Technol., 46 (3-4), 207-219. (2012)

5. Ranjan, S. Khanna, V.S. Moholkar. Appl. Energy. 103, 32-38. (2013)

6. T. Kogo, Y. Yoshida, K. Koganei, H. Matsumoto, T. Watanabe, J. Ogihara, T. Kasumi. Biores. Technol., 233, 67-73. (2017)

7. Singh, N. Singh, N.R. Singh. J. Sci. Ind. Res. 69, 232-237. (2010)

8. H. Abdillah, B. Abdullah, S. Priyanto. Seminar nasional kimia dan pendidikan kimia, 7. ISBN : 978602-73159-0-7.(2015)

9. F.A. Abubakar, O.B. Oloyede. Inter. J. Sci. Res. Manage. 1 (5), 285-291. (2013)

10. B.M. Julia, A.M. Belen, B. Georgina, F. Beatriz. Biocat. Agric. Biotechnol., 6, 1-8. (2016)

11. P.B. Acharya, D.K. Acharya, H.A. Modi. African J. Biotechnol., 17 (22), 4147-4152. (2008)

12. N. Norma, Gamarra, K. Gretty, Villena. Appl Microbiol Biotechnol, 87, 545-551. (2010)

13. F.A. Mostafa, A. Abeer, A. El Aty, R. Eman, B.M. Eid. Biocat. Agric. Biotechnol., 5, 116-122. (2016)

14. Y. H. P. Zhang, M.E. Himmel, J.R. Mielenz. Biotechnol. Adv., 24, 452-481. (2006)

15. R.R. Singhania, R.K. Sukumaran, A.K. Pate., C. Larroche, A. Pandey. Enzyme Microb. Technol., 46, 541-549. (2010)

16. V.H Vu, T.A. Pham, K. Kim. Mycobiol., 39(1), 2025. (2011)

17. Singh, N.R. Bishnoi,N.R. Ind. Crops Prod., 44, 283289. (2013)
18. Abdullah, S. Maftukhah, F. Faradiba, E. Listyaningrum. $15^{\text {th }}$ International Conference on Quality in Research (QiR 2017). (2017)

19. AOAC. Association of Official Analytical Chemist. Official Methods of Analysis $15^{\text {th }}$ Edition, Vol 2.

20. M.I. Asy'ari, and M. Sudibandriyo. Thesis of Universitas Indonesia, (2014).

21. P. Abdeshahian, N. Samat, A. Hamid, W. Yusoff. Biotechnol. Bioproc. Eng., 16, 238-244. (2011)

22. V.T. Rosyida, A.W. Indrianingsih, R. Maryana, S.K. Wahono. Energy Procedia, 65, 368 - 371. (2015)

23. O.H. Lowry, N.J. Rosebrough, A.L. Farr, R.J. Randall. J. Biol. Chem., 193, 265. (1951)

24. G.L. Miller. Analytical Chem 31, 426-428. (1959)

25. R. Singh, A. Shukla, S. Tiwari, M. Srivastava. Renew. Sustain. Energy Rev., 32, 713-728. (2014)

26. F. Cotana, M. Barbanera, D. Foschinia, E. Lascaro. C. Buratti. Energy Procedia, 82, 389-394. (2015)

27. J.S. Kim, Y.Y. Lee, T.H. Kim. Bioresour. Technol., $199,42-48$. (2016)

28. U. Ilyas, A. Majeed, K. Hussain, K. Nawaz, A. Shakil, M. Nadeem. World Appl. Sci. J., 8, 11721178. (2011).

29. J.E. Bailey, D.F. Ollis, D. F. Biochemical Engineering Fundamentals (edition $2^{\text {th }}$ ). New York: McGraw-Hill Book Co.(1986)

30. S. Mrudula, R. Murugamma. Brazilian J. Microbiol., 42, 1119-1127. (2011)

31. Gandjar, A. Oetari, W. Sjamsuridzal. Mikologi dasar dan terapan. Jakarta: Yayasan Obor.(2006)

32. I.B.W. Gunam, K. Buda, I.M.Y.S. Guna. J. Biologi $X I V, 1,55-61$. (2010)

33. S.W. Kang, Y.S. Park, J.S. Lee, S.I. Hong, S.W. Kim. Bioresour. Technol., 91, 153-156. (2004)

34. P. Omojasola, Falakemi., Jilani, O. Priscilla, S.A. Ibiyemi, S. A. Nature Sci., 6(2), 64-79. (2008)

35. S. Kumar, H.K. Sharma, B.C. Sarkar. Food Sci. Biotechnol., 20(5), 1289-1298. (2011)

36. M.L. Shuler, F. Kargi. Bioprosess Engineering Basic Consept. Prenticehall,Inc.(1992)

37. D. Liu, R. Zhang, X. Yang, H. Wu , D. Xu, Z. Tang, Q. Shen. Inter. Biodeterior. Biodegrad., 65, 717-725. (2011)

38. P.S. Delabona, R.D.P.B. Pirota, C.A. Codima, C.G. Tremacoldi, A. Rodrigues, C.S. Farinas. Ind. Crops Prod,.., 42, 236-242. (2013)

39. C.S. Farinas, M.M. Loyo, A. B. Junior, P. W. Tardioli, V.B. Neto, S. Couri. New Biotechnol., 27, 810-815. (2010).

40. S. Putri. UIN Maulana Malik Ibrahim Malang. Skripsi. (2016)

41. D.L. Falkoski, V.M. Guimarães, M.N. Almeida, A.C. Alfenas, J.L. Colodette, S.T. Rezende. Bioresour. Technol., 130, 296-305. (2013)

42. R. Saini, J.K. Saini, M. Adsul, A.K. Patel, A. Mathur, D. Tuli, R.R. Singhania. Bioresour. Technol., vol 188 page 240-246. (2015)

43. D.A. Saropah, A. Jannah, A. Maunatin. Alchemy, 2(1), 34-45. (2012)

44. Lehninger. (1982). Principles of Biochemistry. Worth Publisher, Inc.

45. G.P.G. Putra. J. Biologi, 8(1), 21 -24. (2009) 